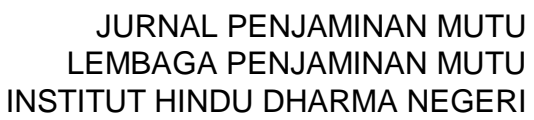

JURNAL PENJAMINAN MUTU

LEMBAGA PENJAMINAN MUTU

INSTITUT HINDU DHARMA NEGERI

DENPASAR
Volume 5 Nomor 2 Agustus 2019

ISSN : 2407-912X (Cetak)

ISSN : 2548-3110 (Online)

http://ejournal.ihdn.ac.id/index.php/JPM

\title{
PENINGKATAN MUTU PENDIDIKAN MELALUI PERENCANAAN MUTU STRATEGIS
}

\author{
Oleh \\ Ketut Bali Sastrawan \\ Sekolah Tinggi Agama Hindu Negeri Mpu Kuturan Singaraja \\ balisastrawan@stahnmpukuturan.ac.id
}

diterima 28 Maret 2019, direvisi 19 Agustus 2019, diterbitkan 31 Agustus 2019

\begin{abstract}
Education is a process of humanizing humans to be able to actualize themselves in life, where good education is education that does not only prepare students for a profession or position, but to solve the problems it faces in daily life. Improving the quality of education is directed at improving the quality of Indonesian human beings through training, thinking, sports, and sports in order to have competitiveness in facing global challenges. Increasing the relevance of education is intended to produce graduates who are in accordance with the demands of the needs of Indonesia's natural resource potential. Steps that can be taken to improve the quality of education, namely: strengthening the curriculum, strengthening the capacity of school management, strengthening educational resources, continuous improvement and fact-based management.
\end{abstract}

Keywords: Education, management, planning, quality

\section{PENDAHULUAN}

Pendidikan

merupakan

proses

memanusiakan manusia agar mampu mengaktualisasikan diri dalam kehidupan, dimana pendidikan yang baik adalah pendidikan yang tidak hanya mempersiapkan para siswanya untuk suatu profesi atau jabatan, tetapi untuk menyelesaikan masalahmasalah yang dihadapinya dalam kehidupan sehari-hari. Idealnya pendidikan tidak hanya mendorong siswa untuk mengembangkan bakat yang disesuaikan dengan ilmu yang di peroleh di sekolah, akan tetapi pendidikan juga bertujuan untuk meningkatkan kualitas manusia yaitu manusia yang beriman dan bertakwa kepada Tuhan Yang Maha Esa, berbudi pekerti luhur, berkepribadian, mandiri, maju, tangguh, cerdas, kreatif, terampil, berdisiplin, beretos kerja, professional, bertanggung jawab, produktif, dan sehat jasmani-rohani. Menurut Undangundang Nomor 20 Tahun 2003 tentang Sistem Pendidikan Nasional (dalam Asyhari et al., 2014), telah jelas menyebutkan bahwa pendidikan nasional berfungsi mengembangkan kemampuan dan 
membentuk watak serta peradaban bangsa yang bermartabat dalam rangka mencerdaskan kehidupan bangsa.

Peningkatan mutu pendidikan diarahkan untuk meningkatkan kualitas manusia Indonesia sutuhnya melalui olahhati, olahpikir, olahrasa, dan olahraga agar memiliki daya saing dalam menghadapi tantangan global. Peningkatan relevansi pendidikan dimaksudkan untuk menghasilkan lulusan yang sesuai dengan tuntutan kebutuhan berbasis potensi sumber daya alam Indonesia. Pendidikan merupakan salah satu kebutuhan hidup manusia yang terpenting dalam usahanya mempertahankan hidup dan mengembangkan dirinya dalam kehidupan bermasyarakat dan bernegara. Maju dan berkembangnya suatu Negara bergantung dari kualitas pendidikannya, sebab melalui pendidikan manusia akan terbebas dari kemiskinan. Dengan pendidikan yang berkualitas akan dihasilkan sumber daya manusia yang berkualitas pula, sehingga mampu mengembangkan kemampuan berpikir agar melek ilmpu pengetahuan teknologi (IPTEK) serta mampu mengikuti dan memanfaatkan perkembangannya.

Sekolah sebagai wadah pembentukan karakter diharapkan dapat mempersiapkan peserta didik untuk memiliki jati diri berdasarkan nilai-nilai bangsa tanpa menolah pandangan baru dalam proses modernisasi, sehingga dapat membangun manusia seutuhnya. Kemampuan-kemampuan yang perlu dikuasai generasi di masa yang akan datang disamping penitikberatan pada penguasaan materi dan berpikir rutin, melainkan juga menitik beratkan kepada kemampuan berkomunikasi, kreatif, berpikir jernih, dan kritis dengan mempertimbangkan segi moral suatu permasalahan, menjadi warga negara yang bertanggung jawab, toleran, hidup dalam masyarakat yang mengglobal, serta memiliki minat luas dalam kehidupan, kesiapan untuk bekerja, kecerdasan sesuai dengan bakat atau minatnya, dan rasa tanggungjawab terhadap lingkungan.
Mutu pendidikan mengandung makna yang berlainan. Namun, perlu ada suatu pengertian yang operasional sebagi suatu pedoman dalam pengelolaan pendidikan untuk sampai pada pengertian mutu pendidikan, kita lihat terlebih dahulu pengertian mutu pendidikan. Menurut kamus besar bahasa Indonesia, Mutu adalah ukuran baik buruk suatu benda, keadaan, taraf atau derajad (kepandaian, kecerdasan, dan sebagainya).

Menurut Hamalik (2006), mutu dapat dilihat dari dua sisi, yaitu segi normatif dan segi deskriptif, dalam artian normatif, mutu ditentukan berdasarkan pertimbangan (kriteria) intrinsik dan ekstrinsik. Berdasarkan kritria intrisik, mutu pendidikan merupakan produk pendidikan yakni. manusia yang terdidik. Sesuai dengan standar ideal. Berdasarkan kriteria ekstrinsik, pendidikan merupakan instrumen untuk mendidik. tenaga kerja. yang terlatih. Dalam artian deskriptif, mutu ditentukan berdasarkan keadaan senyatanya, misalkan hasil tes prestasi belajar. Korelasi mutu dengan pendidikan, mutu pendidikan adalah kemampuan sekolah dalam pengelolaan secara operasional an efisien tehadap komponen-komponen yang berkaitan dengan sekolah sehingga menghasilkan nilai tambah terhadap komponen tersebut menurut norma/ standar yang berlaku. Dari penjelasan diatas dapat disimpulkan bahwa bicara pendidikan bukanlah upaya sederhana, melainkan suatu kegiatan dinamis dan penuh tantangan. Pendidikan selalu berubah seiring dengan perubahan jaman. Oleh karena itu pendidikan senantiasa memerlukan upaya perbaikan dan peningkatan mutu sejalan dengan semakin tingginya kebutuhan dan tuntunan kehidupan masyarakat.

Dalam konteks pendidikan, pengertian mutu dalam hal ini mengacu pada konteks hasil pendidikan mengacu pada prestasi yang dicapai oleh sekolah pada setiap kurun waktu tertentu setiap catur wulan, semester, setahun, 5 tahun dan sebagainya). Prestasi yang dicapai dapat berupa hasil test kemampuan akademis (misalnya ulangan umum, UN, dan lain-lain), dapat pula 
prestasi di bidang lain misalnya dalam cabang olah raga atau seni. Bahkan prestasi sekolah dapat berupa kondisi yang tidak dapat dipegang intangible seperti suasana disiplin. Keakraban, saling menghormati dan sebagainya. Dalam .proses pendidikan. yang bermutu terlibat berbagai input. Seperti: bahan ajar (kognitif, afektif, atau psikomotorik), metodologi (bervariasi sesuai kemampuan guru), sarana sekolah dukungan administrasi dan sarana prasarana, dan sumber daya lainnya serta penciptaan suasana yang kondusif. Manajemen sekolah, dukungan kelas mensinkronkan berbagai input tersebut atau mensinergikan semua komponen dalam interaksi (proses) belajar mengajar baik antara guru, siswa dan sarana pendukung di kelas maupun di luar kelas, baik konteks kurikuler maupun ekstra kurikuler, baik dalam lingkup substansi yang akademis maupun yang non akademis dalam suasana yang mendukung proses pembelajaran.

Antara proses dan pendidikan yang bermutu saling berhubungan. Akan tetapi agar proses itu tidak salah arah, maka mutu dalam arti hasil output harus dirumuskan terlebih dahulu oleh sekolah, dan jelas target yang akan dicapai untuk setiap tahun kurun waktu tertentu. Berbagai input dan proses harus selalu mengacu pada mutu hasil output yang ingin dicapai. Adapun instrumental input, yaitu alat berinteraksi dengan raw input (siswa) seperti guru yang harus memiliki komitmen yang tinggi dan total serta kesadaran untuk berubah dan mau berubah untuk maju, menguasai ajar dan metode mengajar yang tepat, kreatif, dengan ide dan gagasan baru tentang cara mengajar maupun materi ajar, membangun kenerja dan disiplin diri yang baik dan mempunyai sikap positif dan antusias terhadap siswa, bahwa mereka mau diajar dan mau belajar. Kemudian sarana dan prasarana belajar harus tersedia dalam kondisi layak pakai, bervariasi sesuai kebutuhan, alat peraga sesuai dengan kebutuhan, media belajar disiapkan sesuai kebutuhan. Biaya pendidikan dengan sumber dana, budgeting, kontrol dengan pembukuan yang jelas.
Kurikulum yang memuat pokok-pokok materi ajar yang sesuai dengan tujuan pembelajaran, realistik, sesuai dengan fenomena kehidupan yang sedang dihadapi. Tidak kalah penting metode mengajar pun harus dipilih secara variatif, disesuaikan dengan keadaan, artinya guru harus menguasai berbagai metode. Begitu pula dengan raw input dan lingkungan, yaitu siswa itu sendiri. Dukungan orang tua dalam hal ini memiliki kepedulian terhadap penyelenggaraan pendidikan, selalu mengingatkan dan peduli pada proses belajar anak di rumah maupun di sekolah.

\section{PEMBAHASAN}

\subsection{Langkah-langkah Peningkatan Mutu dalam Pendidikan}

Upaya perbaikan pada lembaga pendidikan tidak sederhana yang dipikirkan karena butuh perbaikan yang berkelanjutan, berikut ini langkahlangkah dalam meningkatkan mutu pendidikan.

\section{A. Memperkuat Kurikulum}

Kurikulum adalah instrumen pendidikan yang sangat penting dan strategis dalam menata pengalaman belajar siswa, dalam meletakkan landasan-landasan pengetahuan, nilai, keterampilan,dan keahlian, dan dalam membentuk atribut kapasitas yang diperlukan untuk menghadapi perubahan-perubahan sosial yang terjadi. Saat ini, memang telah dilakukan upaya-upaya untuk semakin meningkatkan relevansi kurikulum dengan melakukan revisi dan uji coba kurikulum berbasis kompetensi (KBK). Kurikulum uji coba tersebut didasarkan pada pendekatan yaitu: (1) Pengasaan aspek kognitif dalam bentuk kemampuan, (2) penguasaan aspek afektif yang lebih komprehensif, dan (3) penguasaan aspek keterampilan dalam bentuk kapasitas profesional. Kompetensi itu hendaknya dapat membentuk suatu kapasitas yang utuh dan komprehensif sehingga tidak 
diredusir menjadi keterampilan siap pakai. Michael, (2002), Charles quengly (2000) mengemukakan kompetensi yang berada dalam suatu keutuhan dan komprehensif dengan kapasitas lainnya. Kompetensi mensyaratkan tiga elemen dasar yaitu basic, knowledge, skill ( intellectual skill, participation skill), and disposition. Melalui proses pembelajaran yang efektif, dari tiga elemen dasar ini dapat dibentuk kompetensi dan komitmen untuk setiap keputusan yang diambil. Kapasitas ini harus menjadi muatan utama kurikulum dan menjadi landasan bagi pengembangan proses pembelajaran dalam rangka pembentukan kompetensi.

B. Memperkuat Kapasitas Manajemen Sekolah

Dewasa ini telah banyak digunakan model-model dan prinsip-prinsip manajemen modern terutama dalam dunia bisnis untuk kemudian diadopsi dalam dunia pendidikan. Salah satu model yang diadopsi dalam dunia pendidikan. Salah satu model yang diadopsi adalah . School Based Management. Dalam rangka desentralisasi di bidang pendidikan, model ini mulai dikembangkan untuk diterapkan. Diproposisikan bahwa manajemen berbasis sekolah (MBS) : (1) akan memperkuat rujukan referensi nilai yang dianggap strategis dalam arti memperkuat relevansi, (2) memperkuat partisipasi masyarakat dalam keseluruhan Kegiatan pendidikan, (3) memperkuat preferensi nilai pada kemandirian dan kreativitas baik individu maupun kelembagaan, dan (4) memperkuat dan mempertinggi kebermaknaan fungsi kelembagaan sekolah.

C. Memperkuat Sumber Daya Pendidikan

Sumber daya kependidikan ada beberapa jenis, yaitu:
1. Memperkuat Sistem Pendidikan Tenaga Kependidikan

Dalam jangka panjang, agenda utama upaya memperkuat sumber daya tenaga kependidikan ialah dengan memperkuat sistem pendidikan dan tenaga kependidikan yang memiliki keahlian. Keahlian baru itu adalah modal manusia (human investmen), dan memerlukan perubahan dalam sistem pembelajarannya. Abad ke-21 perolehan keahlian itu memerlukan perubahan dalam sistem pembelajaran karena alasan: (1) keahlian yang diperlukan untuk mencapai keberhasilan akan semakin tinggi dan berubah sangat cepat, (2) Keahlian yang diperlukan sangat tergantung pada teknlogi dan inovasi baru, maka banyak dari keahlian itu harus dikembangkan dan dilatih melalui pelatihan dalam pekerjaan, dan (3) kebutuhan akan keahlian itu didasarkan pada keahlian individu.

2. Memperkuat Kepemimpinan

Dalam fondasi berbagai karakteristik pribadi, pimpinan lembaga pendidikan perlu menciptakan visi untuk mengarahkan lembaga pendidikan dan karyawannya. Dalam konteks ini, penciptaan visi yang jelas akan menumbuhkan komitmen karyawan terhadap kwalitas, memfokuskan semua upaya lembaga pendidikan pada rumusan kebutuhan pengguna jasa pendidikan, menumbuhkan sense of team work dalam pekerjaan, menumbuhkan standard of excellence, dan menjebatani keadaan lembaga pendidikan sekarang dan masa yang akan datang. 
3. Meningkatkan Mutu Mengajar Melaui Program Inovatif Berbasis Kompetensi

Selama ini sekolah terutama guru masih sangat terbatas dalam melakukan inovasi-inovasi pembelajaran. Disisi lain, upaya untuk memperkuat kemampuan mengajar telah diupayakan melalui berbagai jenis penataran, pendidikan, ataupun pelatihanpelatihan. Melalui berbagai kegiatan tersebut dikenalkan pada inovasi-inovasi pembelajaran. Tetapi dari pengalaman empirik tampaknya upaya-upaya itu belum secara signifikan membawa perubahan dalam arti peningkatan mutu hasil belajar. Pengembangan bahan ajar, pengembangan strategi dan metode pembelajaran, pengembangan sistem evaluasi, dan pengembangan MBS.

Kebutuhan akan inovasi itu dapat dilihat dalam dua hal yaitu untuk kepentingan inventions dan untuk kepentingan perubahan kultural sekolah, sehingga terbangun suatu kultur yang (1) berorientasi inovasi, (2) menumbuhkan kebutuhan untuk terus maju dan meningkat, (3) kebutuhan untuk berprestasi, (4) inovasi adalah sebagai suatu kebutuhan.

4. Mengoptimalkan Fungsi-Fungsi Tenaga Pendidik

Di sekolah-sekolah selama ini yang berperan utama adalah guru. Seorang guru melaksanakan berbagai fungsi baik fungsi mengajar, konselor, teknisi, maupun pustakawan. Bahkan, dalam kasus-kasus tertentu terdapat guru mengajar bukan berdasarkan keahliannya. Kondisi ini jelas kurang menguntungkan bagi terselenggaranya suatu proses pendidikan yang baik diperlukan fungsi-fungsi kependidikan yang saling mendukung, sehingga dapat dicapai suatu hasil yang maksimal.

D. Perbaikan yang berkesinambungan Perbaikan yang berkesinambungan berkaitan dengan komitmen (Continuos quality Improvement atau CQI) dan proses Continuous pross Improvement. Komitmen terhadap kualitas dimulai dengan pernyataan dedikasi pada misi dan visi bersama, serta pembedayaan semua persiapan untuk secara inkrimental mewujudkan visi tersebut (Lewis dan smith, 1994). Perbaikan yang berkesinambungan tergantung kepada dua unsur. Pertama, mempelajari proses, alat, dan keterampilan yang tepat. Kedua, menerapkan keterampilan baru small achieveable project. Proses perbaian berkesinambungan yang dapat dilakukan berdasarkan siklus PDCA Plan, Do, Check, Action. Siklus ini merupakan siklus perbaikan yang never ending, dan berlaku pada semua fase organisasi/lembaga.

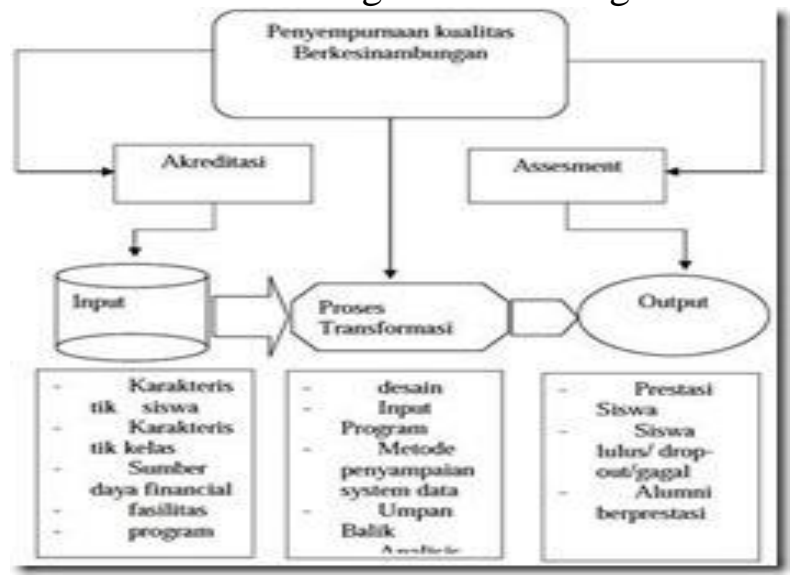

Gambar 1: Penyempurnaan kualitas berkesinambungan dalam pendidikan

E. Manajemen berdasarkan fakta Pengambilan keputusan harus didasarkan pada fakta yang nyata tentang kualitas yang didapatkan dari berbagai sumber diseluruh jajaran organisasi. Jadi, tidak semata-mata atas dasar intuisi, praduga, atau organizational politik. Berbagai alat telah dirancang dan dikembangkan 
untuk mendukung pengumpulan dan analisis data, serta pengambilan keputusan berdasarkan fakta.

Sebenarnya banyak sekali aspek yang turut menentukan mutu pendidikan di sekolah. Edward sallis (1993:2) mengemukakan bahwa yang menentuan mutu pendidikan mencakup aspek-aspek berikut: pembinaan yang berkelanjutan, guru yang profesional, nilai-nilai moral yang luhur, hasil ujian ynag gemilang, dukungan orang tua, komunitas bisnis dan komunitas lokal, kepemimpinan yang tangguh dan berarah tujuan, kepedulian dan pehatian pada anak didik, kurikulum yang seimbang, atau kombinasi dari faktor-faktor tersebut Dari sejumlah aspek yang dikemukakan diatas, satu hal yang paling menentukan adalah bagaimana menjalankan manajemen mutu pendidikan itu sendiri Menurut W. Edward deming $80 \%$ dari masalah mutu lebih disebabkan oleh manajemen, dan sisanya $20 \%$ oleh SDM. Hal ini berarti bahwa mutu yang kurang optimal berawal dari manajemen yang tidak profesional dan manajemen yang tidak profsional artinya mencerminkan kepemimpinan dan kebijakan yang tidak profesional pula.

Sejalan dengan konsep itu, dirjen dikdasmen depdiknas (1991:11) menetapkan bahwa ukuran mutu pendidikan disekolah mengacu pada derajad keunggulan setiap komponennya, bersifat relatif, dan selalu ada dalam perbandingan. Ukuran sekolah yang baik bukan semata-mata dilihat dari kesempurnaan komponennya dan kekuatan yang di milikinya, melainkan diukur dari kemampuan sekolah dalam mengantsipasi perubahan, konfik, serta kekurangan atau kelemahan yang ada dalam sekolah tersebut (dengan menggunakan analisis SWOT).
F. Peningkatan Mutu Pendidik

Upaya peningkatan mutu pendidikan dipengaruhi oleh faktor majemuk. Faktor yang satu saling berpengaruh terhadap faktor yang lainnya. Namun demikian, faktor yang paling penting adalah guru, karena hitam-putihnya proses belajar mengajar di dalam kelas banyak dipengaruhi oleh mutu gurunya. Guru dikenal sebagai 'hidden currickulum' atau kurikulum tersembunyi, karena sikap dan tingkah laku, penampilan profesional, kemampuan individual, dan apa saja yang melekat pada pribadi sang guru, akan diterima oleh peserta didiknya sebagai rambu-rambu untuk diteladani atau dijadikan bahan pembelajaran. Bagi sebagian besar orangtua siswa, sosok pendidik atau guru masih dipandang sebagai wakil orangtua ketika anak-anaknya tidak berada di dalam keluarga. Fasilitas pendidikan berupa buku sudah demikian canggih disusun. Bahkan banyak bahan ajar yang kini telah disusun dalam bentuk CD ROM, bukan buku yang tebal dan biasanya disusun tidak semenarik komik atau majalah. Dengan demikian peserta didik memiliki pilihan lain berupa sumber informasi yang tinggal 'ngeklik' di komputer pribadinya. Sumber informasi dengan mudah dicari dengan cara 'surfing' melalui bahan ajar virtual melalui internet.

Pada era teknologi informasi, guru memang tidak lagi dapat berperan sebagai satu-satunya sumber informasi dan ilmu pengetahuan. Peran guru telah berubah lebih menjadi fasilitator, motivator, dan dinamisator bagi peserta didik. Dalam era teknologi informasi peserta didik dengan mudah dapat mengakses informasi apa saja yang tersedia melalui internet. Dalam kondisi seperti itu, maka guru diharapkan dapat memberikan peran yang lebih besar untuk memberikan rambu- 
rambu etika dan moral dalam memilih informasi yang diperlukan. Dengan kata lain, peran pendidik tidak dapat digantikan oleh apa dan siapa, serta dalam era apa saja. Untuk dapat melaksanakan peran tersebut secara efektif dalam proses pendidikan, pendidik dan tenaga kependidikan harus ditingkatkan mutunya dengan skenario yang jelas.

Kemudian kompetensi kepribadian seorang guru harus mempunyai kepribadian yang baik agar menjadi contoh untuk anak didiknya, kompetensi sosial disini adanya interaksi yang baik antara guru dan siswa, baik dalam kegiatan proses belajar mengajar maupun diluar jam pelajaran. Selanjutnya kompetensi profesional yang diperoleh melalui pendidikan profesi seorang guru harus menguasai sepenuhnya materi yang akan ia ajarkan kepada anak didiknya tentunya sesuai bidang yang ia geluti. Selain itu, sertifikat pendidik sebagaimana yang dimaksud disini yaitu yang diberikan kepada guru yang telah memenuhi persyaratan, sehat jasmani dan rohani, dengan kualifikasi tersebut akhirnya akan mendapatkan sumber daya manusia yang berkualitas serta memiliki kemampuan untuk mewujudkan tujuan pendidikan nasional.

Sehingga sekolah dapat mengetahui kendala- kendala yang ada dan dapat mengatasinya dengan baik. Dengan demikian, secara teoritis rekrutmen guru merupakan hal yang sangat penting tentunya rekrutmen yang dilakukan harus sesuai dengan kebutuhan dan persyaratan yang ditentukan oleh sekolah agar mendapatkan sumber daya manusia (SDM) yang berkualitas dan profesional di bidangnya di sebuah lembaga pendidikan. Sebaliknya jika proses rekrutmen yang dilakukan tidak selektif maka akan menghasilkan sumber daya manusia (SDM)yang biasa saja.

\subsection{Strategi Peningkatan Mutu Pendidik}

Untuk meningkatkan kualitas dan kuantitas kegiatan belajar mengajar yang dilakukan oleh guru sebagai tenaga kependidikan, maka profesi guru harus memiliki dan menguasai perencanaan kegiatan belajar mengajar, melaksanakan kegiatan yang direncanakan dan melakukan penilaian terhadap hasil dari proses belajar mengajar. Kemampuan guru dalam merencanakan dan melaksanakan proses pembelajaran merupakan faktor utama dalam mencapai tujuan pengajaran. Keterampilan merencanakan dan melaksanakan proses belajar mengajar ini sesuatu yang erat kaitannya dengan tugas dan tanggung jawab guru sebagai pengajar yang mendidik.

Guru sebagai pendidik mengandung arti yang sangat luas, tidak sebatas memberikan bahan-bahan pengajaran tetapi menjangkau etika dan estetika perilaku dalam menghadapi tantangan kehidupan di masyarakat. Sebagai pengajar, guru hendaknya memiliki perencanaan (planing) pengajaran yang cukup matang. Perencanaan pengajaran tersebut erat kaitannya dengan berbagai unsur seperti tujuan pengajaran, bahan pengajaran, kegiatan belajar, metode mengajar, dan evaluasi. Unsur-unsur tersebut merupakan bagian integral dari keseluruhan tanggung jawab guru dalam proses pembelajaran.

Secara umum terdapat beberapa langkah strategi yang dapat diimplementasikan dalam lingkungan kependidikan dengan tujuan bahwa peningkatan mutu pendidik dan tenaga kependidikan akan behasil melalui strategi- strategi berikut ini:

A. Evaluasi diri self assessment

Evaluasi diri sebagai langkah awal bagi setiap sekolah yang ingin, atau menerncanakan untuk meningkatkan kualitas sumber daya manusia. Kegiatan ini dimulai dengan curah 
pendapat brainstorming yang diikuti oleh kepala sekolah, guru, dan seluruh staf, dan diikuti juga anggota komite sekolah. Prakarsa dan pimpinan rapat adalah kepala sekolah. Untuk memancing minat acara rapat dapat dimulai dengan pertanyaan seperti: Perlukah kita meningkatkan mutu? seperti apakah kondisi sekolah / madrasah kita dalam hal mutu pada saat ini? Mengapa sekolah kita tidak/belum bermutu?

Kegiatan evalusi diri ini bertujuan untuk mengetahui kondisi sekolah saat ini dalam segala aspeknya (seluruh komponen sekolah), kemajuan yang telah dicapai, maupun masalah-masalah yang dihadapi ataupun kelemahan yang dialami. Kegiatan evaluasi diri ini juga merupakan refleksi/mawas diri, untuk membangkitkan kesadaran / keprihatinan akan penting dan perlunya pendidikan yang bermutu, sehingga timbul komitmen bersama untuk meningkatkan mutu sense of quality, serta merumuskan titik tolak point of departure bagi sekolah/madrasah yang ingin atau akan mengembangkan diri terutama dalam hal mutu. Titik awal ini penting karena sekolah yang sudah berjalan untuk memperbaiki mutu, mereka tidak berangkat dari nol, melainkan dari kondisi yang dimiliki.

B. Perumusan Visi, Misi, dan tujuan Bagi pihak sekolah yang baru berdiri atau baru didirikan, perumusan visi dan misi serta tujuan merupakan langkah awal / pertama yang harus dilakukan yang menjelaskan kemana arah pendidikan yang ingin dituju oleh para pendiri/ penyelenggara pendidikan. Dalam kasus sekolah/madrasah negeri kepala sekolah bersama guru mewakili pemerintah kab/kota sebagai pendiri dan bersama wakil masyarakat setempat ataupun orang tua siswa harus merumuskan kemana sekolah kemasa depan akan dibawa, sejauh tidak bertentangan dengan tujuan pendidikan nasional seperti tercantum dalam UU Nomor 23 tahun 2003 tentang Sistem Pendidikan Nasional. Kondisi yang diharapkan / diinginkan dan diimpikan dalam jangka panjang itu, kalau dirumuskan secara singkat dan menyeluruh disebut visi. Keadaan yang diinginkan tersebut hendaklah ada kaitannya dengan idealisme dan mutu pendidikan. Idealisme disini dapat berkaitan dengan kebangsaan, kemanusiaan, keadilan, keluhuran budi pekerti, ataupun kualitas pendidikan sebagaimana telah didefinisikan sebelumnya. Sedangkan misi, merupakan jabaran dan visi atau merupakan komponenkomponen pokok yang harus direalisasikan untuk mencapai visi yang telah ditetapkan. Dengan kata lain, misi merupakan tugas-tugas pokok yang harus dilakukan untuk mewujudkan visi.

Tujuan merupakan tahapan antara, atau tonggak tonggak penting antara titik berangkat (kondisi awal) dan titik tiba tujuan akhir yang rumusannya tertuang dalam dalam bentuk visi-misi. Tujuan-tujuan antara ini sebagai tujuan jangka menengah kalau tiba saatnya berakhir (tahun yang ditetapkan ) akan disusul dengan tujuan berikutnya, sedangkan visi dan misi (relatif/pada umumnya)masih tetap. Tujuan (jangka menengah), dipenggalpenggal menjadi tujuan tahunan yang biasa disebut target/sasaran, dalam formulasi yang jelas baik secara kualitatif maupun kuantitatif. Tujuantujuan jangka pendek (1 tahun) inilah yang rincian persiapannya dalam bentuk perencanaan.

C. Perencanaan

Perencanaan pada tingkat sekolah adalah kegiatan yang ditujukan untuk menjawab : apa yang harus dilakukan 
dan bagaimana melakukannnya untuk mewujudkan tujuan (tujuan-tujuan) yang telah ditetapkan / disepakati pada sekolah yang bersangkutan, termasuk anggaran yang diperlukan untuk membiayai kegiatan yang direncanakan. Dengan kata lain perencanaan adalah kegiatan menetapkan lebih dulu tentang apaapa yang harus dilakukan, prosedurnya serta metode pelaksanaannya untuk mencapai suatu tujuan organisasi atau satuan organisasi. Perencanaan oleh sekolah merupakan persiapan yang teliti tentang apa-apa yang akan dilakukan dan skenario melaksanakannya untuk mencapai tujuan yang diharapkan, dalam bentuk tertulis. Dikatakan teliti karena ia harus menjelaskan apa yang akan dilakukan, seberapa besar lingkup cakupan kuantitatif dan kualitatif yang akan dikerjakan, bagaimana, kapan dan berapa perkiraan satuan-satuan biayanya, serta hasil seperti apa yang diharapkan.

D. Pelaksanaan

Apabila kita bertitik tolak dari fungsifungsi manajemen yang umumnya kita kenal sebagai fungsi perencanaan, pengorganisasian, pengarahan/ penggerakkan atau pemimpinan dan kontrol/pengawasan serta evaluasi, maka langkah pertama sampai dengan ketiga dapat digabungkan fungsi perencanaan yang secara keseluruhan (untuk sekolah) sudah dibahas. Didalam pelaksanaan tentu masih ada kegiatan perencanaanperencanaan yang lebih mikro (kecil) baik yang terkait dengan penggalan waktu (bulanan,semesteran, bahkan mingguan), atau yang terkait erat dengan kegiatan khusus, misalnya menghadapi lomba bidang studi, atau kegiatan lainnya.

Tahap pelaksanaan, dalam hal ini pada dasarnya menjawab bagaimana semua fungsi manajemen sebagai suatu proses untuk mencapai tujuan lembaga yang telah ditetapkan melalui kerjasama dengan orang lain dan dengan sumber daya yang ada, dapat berjalan sebagaimana mestinya (efektif dan efisien). Pelaksanaan juga dapat diartikan sebagai suatu proses kegiatan merealisasikan apaapa yang telah direncanakan.

E. Evaluasi

Evaluasi sebagai salah satu langkah strategi dalam meningkatkan mutu pendidik dan tenaga kependidikan, merupakan kegiatan yang penting untuk mengetahui kemajuan ataupun hasil yang dicapai oleh sekolah didalam melaksanakan fungsinya sesuai rencana yang telah dibuat sendiri oleh masing-masing sekolah. Evaluasi pada tahap ini adalah evaluasi menyeluruh, menyangkut pengelolaan semua bidang dalam satuan pendidikan yaitu bidang teknis edukatif (pelaksanaan kurikulum /proses pembelajaran dengan segala aspeknya), bidang ketenagaan, bidang keuangan, bidang sarana prasarana dan administrasi ketatalaksanaan sekolah. Sungguh pun demikian, bidang teknis edukatif harus menjadi sorotan utama dengan focus pada capaian hasil (prestasi belajar siswa).

F. Pelaporan

Pelaporan disini diartikan sebagai pemberian atau penyampaian informasi tertulis dan resmi kepada berbagai pihak yang berkepentingan stake hokders, mengenai aktifitas manajemen satuan pendidikan dan hasil yang dicapai dalam kurun waktu tertentu berdasarkan rencana dan aturan yang telah ditetapkan sebagai bentuk pertanggung jawab atas tugas dan fungsi yang diemban oleh satuan pendidikan tersebut.

Kegiatan pelaporan sebenarnya merupakan kelanjutan kegiatan evaluasi dalam bentuk mengkomunikasikan hasil evaluasi 
secara resmi kepada berbagai pihak sebagai pertanggung jawaban mengenai apa-apa yng telah dikerjakan oleh sekolah beserta hasilhasilnya. Hanya perlu dicatat disini bahwa sesuai keperluan dan urgensinya tidak semua hasil evaluasi masuk kedalam laporan (pelaporan). Ada hasil evaluasi tertentu yang pemanfaatannya bersifat internal (untuk kalangan dalam sekolah sendiri), ada yang untuk kepentingan eksternal (pihak luar), bahkan masing-masing stake holder mungkin memerlukan laporan yang berbeda fokusnya. Disamping itu, sebagai dokumen tertulis resmi, yang menyangkut pertanggungjawaban serta reputasi lembaga pendidikan, sungguhpun isinya harus berdsarkan data dan informasi yang benar laporan memiliki tujuan tertentu sesuai dengan peran institusi yang dikirimi atau pembacanya.

Strategi tersebut dalam esensi tertentu sebenarnya sudah diimplementasikan oleh beberapa sekolah yang berada di Indonesia sejak sebelum Indonesia merdeka yang terbukti dengan adanya berbagai lembaga pendidikan swasta (swadaya masyarakat) tumbuh besar, bahkan sebagian besar berbentuk lembaga pendidikan .tradisional. baik yang berlandaskan agama maupun budaya.

\section{KESIMPULAN}

Peningkatan mutu pendidikan diarahkan untuk meningkatkan kualitas manusia Indonesia sutuhnya melalui olahhati, olahpikir, olahrasa, dan olahraga agar memiliki daya saing dalam menghadapi tantangan global. Peningkatan relevansi pendidikan dimaksudkan untuk menghasilkan lulusan yang sesuai dengan tuntutan kebutuhan berbasis potensi sumber daya alam Indonesia. Pendidikan merupakan salah satu kebutuhan hidup manusia yang terpenting dalam usahanya mempertahankan hidup dan mengembangkan dirinya dalam kehidupan bermasyarakat dan bernegara.

Pada era teknologi informasi, guru memang tidak lagi dapat berperan sebagai satu-satunya sumber informasi dan ilmu pengetahuan. Peran guru telah berubah lebih menjadi fasilitator, motivator, dan dinamisator bagi peserta didik. Dalam era teknologi informasi peserta didik dengan mudah dapat mengakses informasi apa saja yang tersedia melalui internet. Dalam kondisi seperti itu, maka guru diharapkan dapat memberikan peran yang lebih besar untuk memberikan rambu-rambu etika dan moral dalam memilih informasi yang diperlukan. Dengan kata lain, peran pendidik tidak dapat digantikan oleh apa dan siapa, serta dalam era apa saja. Untuk dapat melaksanakan peran tersebut secara efektif dalam proses pendidikan, pendidik dan tenaga kependidikan harus ditingkatkan mutunya dengan skenario yang jelas. Kemudian kompetensi kepribadian seorang guru harus mempunyai kepribadian yang baik agar menjadi contoh untuk anak didiknya, kompetensi sosial disini adanya interaksi yang baik antara guru dan siswa, baik dalam kegiatan proses belajar mengajar maupun diluar jam pelajaran. Selanjutnya kompetensi profesional yang diperoleh melalui pendidikan profesi seorang guru harus menguasai sepenuhnya materi yang akan ia ajarkan kepada anak didiknya tentunya sesuai bidang yang ia geluti. Selain itu, sertifikat pendidik sebagaimana yang dimaksud disini yaitu yang diberikan kepada guru yang telah memenuhi persyaratan, sehat jasmani dan rohani, dengan kualifikasi tersebut akhirnya akan mendapatkan sumber daya manusia yang berkualitas serta memiliki kemampuan untuk mewujudkan tujuan pendidikan nasional.

\section{DAFTAR PUSTAKA}

Anderson, J. C. dan Gerbing, D. W. 1991. Structural Equation Modelling in Practice: A Review and Recommended Two-Step Approach. Psychological Bulletin, 193(3), pp. 411- 423. 
Ardhana, W. 1987. Bacaan Pilihan dalam Metode Penelitian Pendidikan. Jakarta: Proyek Pengembangan Lembaga Pendidikan Tenaga Kependidikan Direktorat Jenderal Pendidikan Tinggi Departemen Pendidikan dan Kebudayaan.

Ary, D., Jacobs, L.C., dan Razavich, A. 1985. Introduction to Research in Education. 3rd Ed. New York: Holt, Rinehart and Winston.

Asrorun. 2006. Membangun Profesionalitas Guru. Jakarta : eLSAS.

Best, J.W. 1982. Metodologi Penelilian Pendidikan. Terjemahan Sanafiah Faisal dan Mulyadi Guntur Waseso. Surabaya: Usaha Nasional.

Borg, W.R. dan Gall, M.D. 1983. Educational Research: An Introduction. 4th Ed. New York: Longman.

Cascio, W. F. 1991. Applied Psychology in Personnel Management. Edisi Ke-4. New Jersey: Prentice Hall.

Christina, S., \& Maren, S. 2010. Exporting Services Successfully: Antecedents and Performance Implications of Customer Relationships. Journal of International Marketing, 18(1), pp. 86-108.

Daryanto. 2006. Administrasi Pendidikan. Jakarta: Rineka Cipta.

Depdiknas. 2009. Permendiknas No. 58/2009 tentang standar Tingkat Pencapaian Perkembangan. Jakarta:Depdikbud

Davis, K. \& Newstrom, J. W. 1989. Human Behavior at Work: Organizational Behavior 8th edition. New York: McGraw Hill.

Dharma, S. 2010. Manajemen Kinerja, Falsafah Teori \& Penerapannya, Yogyakarta: Pustaka Pelajar

Hamalik. 2006. Pendidikan Guru Berdasarkan Pendekatan Kompetensi. Jakarta: Bumi Aksara

Kunandar.2007. Guru Profesional : Implementasi Kurikulum Tingkat Satuan Pendidkan Dan Sukses Dalam
Sertifikasi Guru Jakarta: Raja Grafindo persada.

N.K, Roestiyah. 1989. Masalah-masalah Ilmu Keguruan. Jakarta: Bina Aksara.

Rosyada. 2004. Paradigma Pendidikan Demokratis: Sebuah Model Pelibatan Masyarakat Dalam Penyelenggaraan Pendidikan. Jakarta: Prenada Media.

Samana, A. Profesionalisme Keguruan, Yogyakarta : Kanisius, 1994

Usman, M. 2005. Menjadi Guru Profesional.Bandung: PT. Remaja Rosdakarya.2005

Anastasi, A. 1982. Psychological Testing. (4th ed.). London: Collier MacMillan Publishers. 